\title{
International Regulation of Driftnet Fishing: The Role of Environmental Activism and Leverage Diplomacy
}

\section{INTRODUGTION}

The latter half of the twentieth century may well be remembered for both the gravity of human-induced environmental destruction and the birth of an earth-wide environmental human conscience. These environmental issues transcend national boundaries to encompass global issues. ${ }^{1}$

[A]s humanity believes increasingly that in a theoretical sense the planet belongs to all . . . the notion of legitimate interests seems to extend far beyond traditional notions of harms. Consequently, there is a perception that all have an interest in preventing the loss of a species, the destruction of cultural heritage, and the waste of natural resources. ${ }^{2}$

In the United States, interest in the preservation of American wilderness and the ecological diversity contained therein became part of the agenda of the national government after the Civil War and was a prominent issue during the presidency of Theodore Roosevelt in the early part of this century. The creation of Yellowstone National Park, ${ }^{3}$ with its unique geological features and threatened wildlife, was representative of America's concern for diminishing wilderness, but that concern was domestic in its focus. Whether Brazil and its people were destroying the Amazon rain forest was considered irrelevant for Americans, since the area was so vast and remote and most Americans had no idea of the global implications of deforestation. Environmental issues were localized and generally confined within national borders or between contiguous nations.

1. Stockholm Declaration on the Human Environment, adopted by the UN Conference on the Human Environment at Stockholm, June 16, 1972, Section I of Report of the United Nations Conference on the Human Environment, U.N. Doc. A/CONF.48/14 and Corr.1 (1972), reprinted in 11 I.L.M. 1416 (1972) [hereinafter "Stockholm Declaration"].

2. Caron, The Law of the Environment: A Symbolic Step of Modest Value, 14 Y ALE J. INT'L L. 528, 529 (1989).

3. Yellowstone National Park was the first area in the United States designated a national park and wilderness area in 1872. 12 ENCYCLOPAEDIA BRITANNICA, 833 (15th Ed. 1986). 
Historically, the vast common oceans of the world have been important to many nations for various purposes: the ocean's natural resources, for commerce and transportation, and for the dumping of garbage. Environmental concerns about the exploitation or pollution of the marine environment, if those concerns were expressed at all, extended only to a particular nation's coastline or waterways. ${ }^{4}$ Conflict between nations over the navigational use of seas and waterways dates from ancient times; the Punic Wars between Rome and Carthage were conflicts over the control of shipping lanes and ports to determine who would control trade in the Western Mediterranean. ${ }^{5}$ The living and mineral marine resources that were found beyond the coastlines and an approximately two to three mile territorial zone ${ }^{6}$ were considered the property of all people. As long as the resources seemed plentiful, the freedom of all nations to harvest the bounty of the oceans in an unlimited fashion was generally unquestioned.?

Conflicts over fishing practices on the high seas are an outgrowth of the twentieth century realization that the oceans are not as vast and inexhaustible as once thought. Efficient and extensive whaling has brought many species of cetaceans to the brink of extinction. ${ }^{8}$ Large scale driftnets, which indiscriminately trap everything that enters them, have significant effects on many populations of marine life. ${ }^{9}$ Consequently, the driftnetting practices of Taiwan in the North Pacific and the decision of Norway to resume whaling can no longer be viewed solely as the responsibility or concern of Taiwan and Norway. What one nation does in its exploitation of the high seas has consequences

4. Regulation of fishing methods in rivers and inland waters dates back to the Middle Ages. See Johnston, The Driftnetting Problem in the Pacific Ocean: Legal Considerations and Diplomatic Options, 21 Ocean Dev. \& INT'L. L., 5,7 (1990).

5. 20 Encyclopaedia Britannica 317-21 (15th Ed. 1986).

6. Krueger \& Nordquist, The Evolution of the 200-mile Exclusive Economic Zone: State Practice in the Pacific Basin, 19 VA. J. INT'L L. 321, 322 (1979).

7. Fishing for Salmon in North America has historically been regulated. See J.A. Gulland, The Management of Marine Fisheries (1974), quoted in Johnston, supra note 4 , at 27 n. 23 .

8. "[T]he history of whaling has seen overfishing of one area after another and of one species of whale after another to near extinction." International Convention for the Regulation of Whaling, preamble, Dec 2, 1946, 62 Stat. 1716, T.I.A.S. No. 1849,161 U.N.T.S. 72.

9. High Seas Driftnet Fishing: Hearing before the National Ocean Policy Study of the Senate Committee on Commerce, Science, and Transportation, 102nd Cong., 1st Sess. 30 (1991) (statement of Dr. Michael F. Tillman, Deputy Assistant Administrator for Fisheries, National Marine Fisheries Service, National Oceanic and Atmospheric Administration, U.S. Department of Commerce) [hereinafter "Senate Hearing"]. 
that impact every other nation that utilizes marine resources. The exploitation also raises conservation protests from independent environmental groups because of threats to endangered species, pollution, and destruction of the oceans' ecosystems. The oceans are common territory that neither belong to a particular nation nor to the human race as a species. "The environment belongs to all of us. In this new world of freedom the world citizens must enjoy this common trust for generations to come." 10

Global environmental problems present international law with the challenge to address the tragedy of the commons." "Ruin is the destination toward which all men rush, each pursuing his own best interest in a society which believes in the freedom of the commons. Freedom in a commons brings ruin to all." 12 This Note will address the ways in which international law has thus far dealt with an environmental issue of the commons of the high seas: large-scale pelagic driftnet fishing. Nations have been reluctant to surrender individual autonomy in the exploitation of marine resources. Treaties and customary law are the sources of hard international law, defined as law which is considered binding by nations. Hard law has achieved limited success in regulating fishing practices on the high seas. Soft law, often contained in declarations, is not binding but carries persuasive weight; soft law, leverage diplomacy, and public awareness created by activist environmental groups have been critical in promoting and forcing change in international treaties and resolutions which address large-scale driftnet fishing. This Note will first explore the sources of international environmental law. It will then trace the regulation, or lack thereof, in the practice of driftnet fishing and the roles that environmental activism and leverage diplomacy have, or are likely to play, in international regulation of these activities.

\section{Sources of International Law}

International law consists of hard law: that which has been negotiated and ratified in treaties or law which has its source in state custom or practice of a long-standing nature. ${ }^{13}$ The nature of global environmental problems involves factors which make it difficult to apply

10. President George H. W. Bush, Excerpts from Bush's Speech at the Opening of the U.N. General Assembly, N.Y. Times, Sept. 26, 1989, at A8.

11. Hardin, The Tragedy of the Commons, reprinted in Economics, Ecolocy, AND ETHics 100 (H. Daly ed. 1973) [hereinafter "Hardin"].

12. Id. at 104 .

13. Geoffery Palmer, New Ways to Make International Environmental Law, 86 Ам. J. INT'L L., 259, 269 (1992). 
and solve these problems primarily with hard international law. Three factors contribute to this difficulty: the formidable nature of environmental issues being negotiated; the condition of the international organizations relating to the environment, particularly the U.N. system; and those methods currently used to make international law. ${ }^{14}$ Addressing such issues as ozone depletion, climatic change, reduction of bio-diversity, or disposal of nuclear waste requires the input of the world's scientific community, political leaders, business interests, agricultural interests, and health professionals. Global environmental issues can be discussed in terms of security.

[I]f global environmental security is taken to mean security against those risks that threaten our common survival, the focus of collective legal action may indeed be sharpened considerably. A tentative priority list of genuine survival risks would thus, as a minimum, have to include the following essential concerns: climatic security, biological security, chemical security. ${ }^{15}$

Considering the complexity of world environmental problems, the lack of a U.N. institutional organ to deal with the environment is illustrative of how recently these problems have been recognized. "In no respect is the [U.N.] Charter more a product of its times than in its disregard of the environment. Aside from a reference to 'good neighborliness', it contains nothing." 16 Environmental tasks are spread among different U.N. agencies, including the World Health Organization, the Food and Agricultural Organization, and the International Maritime Organization. The UN Environment Programme (UNEP) was established by a General Assembly resolution to stimulate environmental action and coordination. ${ }^{17}$ UNEP can claim some successes, but has no formal powers and as presently constituted is an inadequate organ for the magnitude of world environmental problems. ${ }^{18}$ Why has the U.N. not been restructured to create an environmental agency with the scope

14. Id. at 259 .

15. P. Sand, International Law on the Agenda of the United Nations Conference on Environment and Development 15 (unpublished paper on file, Victoria University of Wellington), quoted in Palmer, supra note 13, at 260.

16. Palmer, supra note 13 , at 260 .

17. Institutional and Financial Arrangements for International Environmental Co-operation, G.A. Res. 2997, U.N. GAOR, 27th Sess., Supp. No. 30 at 43, U.N. Doc. A/8730 (1972).

18. See Palmer, supra note 13, at 261-63 for a discussion of UNEP and its accomplishments and limitations. 
and power to adequately address these problems? Inaction on the part of member nations may well be explained by their hesitancy to surrender any autonomy.

To produce the conditions necessary for sustainable development, a great deal more in the way of regulation and prohibition will be required at the international level than we have been prepared to tolerate up to now . . . both developed and developing countries have an interest in resisting changetheir freedom of action as nations is likely to be reduced and they know it-hence the lack of enthusiasm for new institutions and methods of international lawmaking. ${ }^{19}$

\section{Methods of Making International Law}

\section{A. Customary International Law}

Customary international law exists when nations conform their conduct to an "international custom, as evidence of a general practice accepted as law." 20 Customary norms are created by national practice "followed by ... [the nations] from a sense of legal obligation." 21 Customary norms require both acceptance by many nations and widespread observance over a period of time to be accepted as binding law. Since many environmental concerns, including the adverse effects of driftnet fishing on marine ecosystems, have been recognized only recently, customary law offers only modest protection for the environment. ${ }^{22}$ Environmental practices of individual nations have historically been considered the concern of those nations alone, not matters for international regulation. However, as the number of environmental protection treaties between nations increases, the web of legal standards tightens and multiplies the number of occasions on which credible arguments can be made that customary international law has been breached. ${ }^{23}$ While customary international law has the advantage of

19. Id. at 260 .

20. Statute of the International Court of Justice, Art. 38(b), 59 Stat. 1031, T.S. No.993, 1976 U.N.Y.B. 1052.

21. Restatement (Third) of the Foreign Relations Law of the United States, pt. VI, $\$ 102(2)(1987)$.

22. I. Brownlie, A Survey of International Customary Rules of Environmental Protection, 13 Nat. Resources J. 179 (1973).

23. Palmer, supra note 13 , at 264-65. 
flexibility in being able to change as new norms develop and are adopted by nations, "it is not a regulatory system and cannot be turned into one." ${ }^{24}$ Therefore, many global environmental issues that require regulation and monitoring of environmental practices cannot be adequately addressed by customary international law.

\section{B. Treaties}

Treaties form the other branch of hard or binding international law and can be bilateral (between two countries) or multilateral (negotiated and ratified by a number of countries). Many environmental treaties have been negotiated in the past twenty years. ${ }^{25}$ Treaties regulating driftnet fishing will be addressed specifically at a later point in this article. Treaties generally require long negotiation processes and often intentionally lack specificity. ${ }^{26}$ However, the major difficulty in making international law by treaty lies in the principle of consent. ${ }^{27}$ There is an "underlying principle that no State can be bound by any treaty provision unless it has given its assent, and that principle is applicable equally to all types of treaty." 28 Article 11 of The Vienna Convention on the Law of Treaties provides: "The consent of a State to be bound by a treaty may be expressed by signature . . . or by any other means if so agreed." 29 In negotiating multilateral treaties, the requirement that a nation must consent to be bound by a treaty often means negotiating to the lowest common denominator because "a single nation can resist the development of a common position and demand concessions as the price of securing unanimous consent." '30 Since all interested nations must agree on treaty terms, treaty law is often inadequate to effectively regulate environmental problems, because unanimity is difficult to achieve when complex global problems are being negotiated.

24. Id. at 266.

25. Register of International Treaties and other Agreements on the Environment, UN Doc. UNEP/G.C.16/Inf.4 (1991).

26. Palmer, supra note 13 , at 271-72.

27. Id. at 272.

28. A. McNair, The Law of Treaties 162 (1961), quoted in Palmer, supra note 13 , at 272 .

29. Vienna Convention on the Law of Treaties, opened for signature May 23, 1969, U.N. Doc. A/CONF.39/27 (in force Jan. 27, 1980) U.N.T.S. 331, reprinied in 8 I.L.M. 679 (1969).

30. Palmer, supre note 13 , at 264. 


\section{Soft Law}

Soft international law exists when international responsibilities are based on general consensus, rather than on hard law obligations based on treaty law or customary law. ${ }^{31}$ Soft law is often stated in standards that are discretionary but that can produce a climate for the creation of hard law down the road. "Soft law is where international law and international politics combine to build new norms." "32 Soft law relating to the environment can be found in several declarations issued by international conventions.

\section{The Stockholm Declaration of the United Nations Conference on the Human Environment ${ }^{33}$}

The Stockholm Declaration deals with many of the environmental issues of global significance, often in statements that are inconsistent with each other, but does affirm that we have a "solemn responsibility to protect and improve the environment for present and future generations." 34

\section{The Hague Declaration on the Environment ${ }^{35}$}

The Hague Declaration is stated at the level of general principle and avoids details on issues that pose disagreement. ${ }^{36}$ Its significance is that it undertook, by a soft law method, to undermine the rule of unanimous consent. The signatories pledged themselves to promote the development of new institutional authority, within the framework of the United Nations, responsible for combating any further global warming of the atmosphere. That authority shall "involve such decisionmaking procedures as may be effective even if, on occasion, unanimous agreement has not been achieved." 37

Acceptance [of the principle] that nations can be bound without their consent opens the door to a quite different legal context

31. Johnston, supra note 4 , at 21.

32. Palmer, supra note 13 , at 269.

33. Stockholm Declaration, supra note 1.

34. Stockholm Declaration, supra note 1, Principle 1, quoted in Palmer, supra note 13 , at 266 .

35. Hague Declaration on the Environment, March 11, 1989, reprinted in 28 I.L.M. 1308 (1989).

36. Palmer, supra note 13 , at 277.

37. Hague Declaration, supra note 35 , at 1310 , quoted in Palmer, supra note 13, at 278 . 
from that in which international law has developed. It offers the prospect of fashioning an international legislative process for global environmental issues. It offers the practical means of securing the higher standards that may be required by an objective assessment of the scientific evidence, however politically inconvenient a particular measure may be for an individual country. ${ }^{38}$

This departure from the requirement that states must consent in order to be bound by international law has ramifications that are significant for the regulation of driftnet fishing and will be addressed in the discussion of weaknesses in current applicable international law.

\section{The Third United Nations Conference on the Law of the Sea (UNCLOS III) $)^{39}$}

Recognizing the desirability of establishing through this Convention, with due regard for the sovereignty of all States, a legal order for the seas and oceans which will facilitate international communication, and will promote the peaceful uses of the seas and oceans, the equitable and efficient utilization of their resources, the conservation of their living resources, and the study, protection and preservation of the marine environment. ${ }^{40}$

Stated in the preamble of UNCLOS III is the tension that hampers effective regulation of international fishing practices and other environmental marine problems: the hard law principle of national sovereignty to utilize the high seas without interference from other nations versus the soft law norms promoting efforts to conserve and regulate the marine environment to protect it from over-exploitation and destruction. UNCLOS III was opened for signature on December 10, 1982, when 117 states, including Japan and South Korea, became signatories. The United States did not sign because of the convention's provisions relating to the sea bed and the exploitation of its mineral resources. ${ }^{41}$ The treaty is to enter into force 12 months after 60 states

38. Palmer, supra note 13 , at 278 .

39. United Nations Convention on the Law of the Sea, Dec. 10, 1982, U.N. Doc. No. A/Conf.62/122, 21 I.L.M. 1261 (1982).

40. See id. (preamble).

41. President's Statement on United States Oceans Policy, 1 Pub. Papers 378 (1983). 
or parties to the Convention have ratified it. ${ }^{42}$ As provided in the Vienna Convention, "[u]nless a different intention appears from the treaty or is otherwise established, its provisions do not bind a party in relation to any act or fact which took place or any situation which ceased to exist before the date of the entry into force of the treaty with respect to that party." 43 Therefore, UNCLOS III is not yet binding even on signatory nations, but these nations do have an obligation not to frustrate the treaty's goals. ${ }^{44}$

UNCLOS III divides the oceans of the world into three areas: (1) the territorial sea, an adjacent belt of sea to a coastal state not to exceed 12 nautical miles, ${ }^{45}$ (2) the Exclusive Economic Zone (EEZ), an area beyond and adjacent to the territorial sea in which the rights of the coastal nation and the rights of other nations are governed by this convention, ${ }^{46}$ and (3) the high seas, which comprise all parts of the sea that are not included in EEZs, territorial seas, or the internal waters of a nation. ${ }^{47}$ Part $\mathrm{V}$ concerns the rights, jurisdiction and duties of a coastal nation in its EEZ. "With regard to animals occurring in the EEZ of a State, the sovereignty of the State concerned has been explicitly established by article $56 \ldots{ }^{48}$ Article 61 specifies that the coastal state shall determine the allowable catch of the living resources in its EEZ, taking into account the best scientific evidence available to it, and thereby ensuring through proper conservation and management measures that the living resources in the EEZ are not endangered by over-exploitation. Large-scale driftnetting targets migratory species that are found at various times in the EEZs of different coastal nations and on the high seas. Article 64 specifies cooperation directly and through appropriate international organizations among coastal nations and other nations whose nationals fish in a region for highly migratory species with a view to ensuring conservation. Two problems arise in applying these articles to the legal status of highly migratory species. First, there is no definition of highly migratory species

42. UNCLOS III, supra note 39 , art. 308. As of March, 1990,40 states $(2 / 3$ of the required number) had ratified the treaty. Davis, North Pacific Pelagic Driftnelting: Untangling the High Seas Controversy, 64 S. CAL. L. REv. 1057, 1076 n.151 [hereinafter “'Davis"].

43. Vienna Convention, supra note 29, art. 28.

44. See Davis, supra note 42 , at 1077 n. 154.

45. UNCLOS III, supra note 39 , arts. 2 \& 3.

46. UNCLOS III, supra note 39 , part $V$, art. 55.

47. UNCLOS III, supra note 39, part VII, art. 86.

48. Cyril de Klemm, Migratory Species in Intemational Law, 29 NAT. Resources J. 935,938 . 
other than a list of species contained in an annex, ${ }^{49}$ which would be difficult to amend if the need arises to add other species. Second, because article 56, which gives coastal nations sovereign rights over the living resources of their EEZ, makes no exception for highly migratory species, coastal nations are empowered to determine on their own what should be the maximum allowable catch of these species. ${ }^{50}$ "Conversely, where no State has sovereign rights, that is to say in the high seas, animals become international res nullius that anybody may exploit, over-exploit or destroy as he pleases. This latter principle is embodied in international law under the name of freedom of fishing in the high seas." ${ }^{51}$ UNCLOS III enunciates this principle in Article 87(1) and in Article 116. Therefore, even though the comprehensive themes of UNCLOS III are the soft law duties of conserving ${ }^{52}$, cooperating, ${ }^{53}$ and negotiating ${ }^{54}$ to preserve the marine environment and its living resources, nations still can point to the freedom of fishing provisions, which are also in the treaty as justification for the legality of disputed fishing practices. Article 65 applies to marine mammals and allows coastal nations and international organizations to prohibit, limit, or regulate the exploitation of marine mammals more strictly than provided in the treaty, ${ }^{55}$ thereby recognizing the competence of the International Whaling Convention ${ }^{56}$ to regulate whaling wherever it is prosecuted. ${ }^{57}$

\section{High Seas Driftnet Fishing}

\section{A. Impacts of Large-Scale Driftnet Fishing on the Living Marine Environment}

The Department of Commerce released the "Final Report of the 1990 Observations of the Japanese High Seas Squid Driftnet Fishery

49. Id. at 942 .

50. Id.

51. Id. at 938 .

52. The duty to conserve is stated in Articles 117, 119, and 194(5) and, implicitly, in the comprehensive obligation to preserve and protect the marine environment in Article 192. See Johnston, supre note 4, at 22.

53. The duty to cooperate is articulated in Article 197, as well as in provisions relating to highly migratory species (Article 64), marine mammals (Article 65), and anadromous stocks (Article 66). See Johnston, supra note 4, at 22.

54. The duty to negotiate conservation arrangements is stated in Article 118, as well as Articles 64(1) and 66(4). See Johnston, supra note 4, at 22.

55. de Klemm, supra note 48 , at 941 .

56. International Whaling Convention, Dec. 2, 1946, T.I.A.S. No. 1849, 161

U.N.T.S. 72 (signed at Washington, D.C.).

57. de Klemm, supra note 48 , at 941 . 
in the North Pacific Ocean" to the public on June 14, 1991. The report is the result of cooperative efforts by scientists and fishery observers from the United States, Japan, and Canada to determine the catch and bycatch of Japan's 1990 high seas squid driftnet fishery in the North Pacific. The data were collected by 35 United States, 29 Japanese, and 10 Canadian scientific observers on 74 Japanese commercial driftnet vessels.

Scientific' observers reported that in addition to the 7.9 million squid caught by the 74 vessels, 3.2 million pomfret, 252,900 tuna, 81,956 blue sharks, 30,464 sea birds, 1,758 dolphins and 9,747 salmonids were entangled in squid driftnets. The 1990 observer program covered approximately 10 percent of the total Japanese squid driftnet fishery. ${ }^{58}$

"North Pacific stocks of albacore tuna, once the target of a selective hook-and-line troll fishery conducted by United States fishermen, have dramatically declined in recent seasons possibly due to over-fishing by driftnetting nations." 59 "The over-exploitation of sharks is of serious concern. Most species of sharks mature and reproduce very slowly, and hence are extremely susceptible to over-fishing. They also play an important role in the marine ecosystem as apex predators, so their over-exploitation may result in impacts to associated species." 60

If these aforementioned observations are indicative of what is happening elsewhere in the driftnet fisheries-and we have no evidence to indicate otherwise-complete marine ecosystems are being methodically "strip-mined" of their living marine resources-both fish and wildlife. Driftnets are not selective and the data uncovered so far from the 1989 and 1990 observer programs are frighteningly telling. ${ }^{61}$

The United States Congress, after considering data from the scientific observer program on driftnet fishing, made the following findings in the "High Seas Driftnet Fisheries Enforcement Act":62

58. Senate Hearing, supra note 9, at 30 (statement of Michael Tillman).

59. Senate Hearing, supra note 9, at 46 (statement of Ben Deeble, ocean ecology campaigner, Greenpeace).

60. Id.

61. Senate Hearing, supra note 9, at 61 (statement of Albert Manville, II, Ph.D., Senior Staff Wildlife Biologist for Defenders of Wildlife and Chair of the Entanglement Network Coalition).

62. High Seas Driftnet Fisheries Enforcement Act, Pub. L. No. 102-582, 106 Stat. 4901 (amending 16 U.S.C. $\$ 1801$ et seq.). 
(1) Large-scale driftnet fishing on the high seas is highly destructive to the living marine resources and ocean ecosystems of the world's oceans, including anadromous fish and other living marine resources of the United States.

(2) The cumulative effects of large-scale driftnet fishing pose a significant threat to the marine ecosystem, and slow-reproducing species like marine mammals, sharks, and seabirds which may require many years to recover.

(3) Members of the international community have reviewed the best available scientific data on the impacts of large-scale pelagic driftnet fishing, and have failed to conclude that this practice has no significant adverse impacts which threaten the conservation and sustainable management of living marine resources.

\section{B. Regional and U.N. Efforts to Regulate Driftnetting}

Worldwide concern over the destructive effects of large scale driftnet fishing has resulted in action by the U.N. General Assembly. General Assembly resolutions are "collective opinions on particular subjects." "63 Resolutions are not binding as hard international law, but do serve the soft law function of providing discretionary standards for international behavior.

At the very least, widely supported and repeatedly affirmed UN resolutions reflect and articulate agreed upon principles on the basis of which international legal rules can and do develop. Hence, the statement that UN General Assembly resolutions are not binding, although true in a formal sense, contributes little to an understanding of the significant effect these resolutions at times have on the development of international law. ${ }^{64}$

The U.N., via General Assembly Resolutions numbered 44/22565, 45/ $197^{66}$, and most recently $46 / 215^{67}$ (adopted on December 20, 1991),

63. U.N. Charter art. 27, \ 3.

64. T. Buergenthal \& H. Maier, Public International Law 76 (2d ed. 1990 ), quoted in Davis, supra note 41 , at 1082.

65. G.A. Res. $44 / 225$ on driftnet fishing, adopted December 22, 1989, 29 I.L.M. 1555 (1990).

66. G.A. Res. 45/197, 29 I.L.M. 1449 (1990).

67. United Nations: General Assembly Resolution on Large-Scale Pelagic Driftnet Fishing and its Impact on the Living Marine Resources of the World's Oceans and Seas, G.A. Res. 46/215, 31 I.L.M. 241 (1992). 
called for a worldwide moratorium on all high seas driftnet fishing by December 31, 1992, on all the world's oceans, including enclosed seas and semi-enclosed seas.

Before discussing this most recent resolution (G.A. Res. 46/215) and its implications, it is important to briefly outline the agreements and resolutions preceding it.

\section{Regional Agreements}

\section{a. The North Pacific Region}

The chief regional forum for discussion of the high seas driftnetting problem in the North Pacific has been the International North Pacific Fisheries Commission (INPFC), ${ }^{68}$ which was established in 1953 by Canada, Japan, and the United States. The primary focus of this commission was the Japanese high seas salmon fishery in the Northeast Pacific, which was regulated by creating an "abstention line" which prohibited the Japanese from fishing to the east of 175 degrees west longitude. ${ }^{69}$ However, Japanese fleets gradually moved further east; and research by INPFC concluded that significant numbers of maturing and immature salmon of North American origin migrated west of the abstention line and were being exposed to Japanese fishing. Consequently, renegotiations were sought by the United States and Canada, but because any change in the treaty required unanimous agreement, a stalemate existed until $1978 .{ }^{70}$ The adoption by the United States of the Magnuson Fishery Conservation and Management Act in 1976 created a 200-mile Fishery Conservation Zone (FCZ) off the United States coastline and gave the United States control over significant areas that had been fished by the Japanese. ${ }^{72}$ The creation of the FCZ or Exclusive Economic Zone (EEZ) resulted in progress in INPFC negotiations in 1978, but United States concerns about continuing

68. International Convention for the High Seas Fisheries of the North Pacific Ocean, signed at Tokyo, May 9, 1952, 4 U.S.T. 380; T.I.A.S. No. 2786, 25 U.N.T.S. 65 [hereinafter "INPFC'].

69. Senate Hearing, supra note 9, at 50 (statement of David Benton, Director of External and International Fisheries Affairs for the State of Alaska Department of Fish and Game).

70. Id.

71. Magnuson Fishery Conservation and Management Act, Pub. L. No. 94265 (1976); codified, as amended, at 16 U.S.C. SS $1801-1882$ (1988).

72. See Krueger \& Nordquist, supra note 6, quoted in Davis, supra, note 41 . Over $90 \%$ of the world's fish catch occurs within the first 200 miles of coastal state water. 
interceptions of North American salmon led to another round of negotiations in 1985-86 and resulted in a planned phase-out of certain Japanese fishing in the Bering Sea by $1994 .^{73}$ However, large-scale driftnetting for salmon is not precluded under the agreement south of the United States' EEZ. ${ }^{74}$ The INPFC has achieved some cooperation and conservation goals in the regulation of Japanese driftnet fishing where the target fish is salmon, ${ }^{75}$ but, under hard international law, only nations that are parties to an organization and agree to its regulations are bound. ${ }^{76}$ Taiwan and Korea, nations that also have large driftnetting fleets, are not parties to the INPFC.

In the late 1970 s, the squid driftnet fleets of Japan, Korea, and Taiwan began fishing the waters of the North Pacific, and by 1991 "roughly a thousand vessels, with some deploying 40 miles of net a night, [were fishing] the North Pacific"." The Japanese claim "that their vessels are not permitted to engage in pelagic fishing of protected stocks in Convention waters, and that the chief offenders are Taiwanese 'bandits'."78 Various proposals for a broader-based international organization to deal with fishing controversies in the North Pacific have been suggested, ${ }^{79}$ but countries have failed to agree as to which species would be regulated and what acceptable harvests might be.

In the squid fisheries, regulation has been non-existent on the high seas of the North Pacific because there is no broad-based regulatory mechanism that includes all the affected nations. To amend INPFC regulations to totally ban large-scale driftnet fishing by members would require unanimity on the part of Japan, Canada, and the United States ${ }^{80}$ and would still not bind non-member nations. In North America, normally warring factions such as environmentalists, commercial fishermen, fish processors, native Americans, and sport fishermen have joined forces to pressure the governments of Canada and the United

73. Senate Hearing, supra note 9, at 50 (statement of David Benton).

74. Id.

75. Davis, supra note 42 , at 1076.

76. McNair, supra note 28.

77. Senate Hearing, supra note 9 , at 51.

78. Johnston, supra note 4 , at 12.

79. See Johnston, supra note 4 , at 32 n.71-76. Japan, Canada, the United States, the former Soviet Union, and Korea have stated support for a broader-based organization, but have not agreed on what species of fish would be covered or various other issues.

80. INPFC, supra note 68 , art. II. 
States to take national action against driftnetting nations and to support an international ban of the practice. ${ }^{81}$

The establishment of EEZs is one method taken by the United States and other countries to control over-fishing in coastal waters. ${ }^{82}$ However, as more states establish these zones, the traditional high seas commons encompass a smaller area, and more pressure is created to over-fish this area. Without an international mechanism to regulate and conserve living resources on the high seas, the threat posed by large scale driftnetting is only shifted to the commons. ${ }^{83}$

\section{b. The South Pacific Region}

The high seas driftnet tuna fishery has been of extreme concern to the island nations of this area. "Although driftnetting in the South Pacific is on a much smaller scale than the North Pacific, ... its impact on the regional economy is potentially much greater." 84 Many of these islands are developing states with economies highly dependent on the fishery resources within their 200-mile zones. The Forum Fisheries Agency (FFA) was established by 15 nations, including New Zealand and Australia, to attempt to protect their interests in these fishery resources. ${ }^{85}$ Its membership is restricted to regional nations. The FFA functions primarily as a bargaining coalition, but it has been effective in using access to the EEZs of its members to negotiate with nations such as Japan. The practice of driftnetting was particularly threatening in this region because the catch consists largely of "juvenile albacore tuna, which come to the surface between the latitudes of 38 and 41 as they migrate to warmer waters." 86 "During the 1988-89 fishing season, driftnetting fisheries took almost 25,000 tons of albacore, which gave rise to some serious concerns regarding the continued viability of the stock." 87 A treaty prohibiting driftnetting in the EEZs of South Pacific Forum nations was concluded at Wellington, New Zealand, on November $24,1989 .{ }^{88}$ It requires signatories to prohibit

81. Johnston, supra note 4 , at 13.

82. Johnston, supra note 4 , at 31 n.61. Five of the North Pacific nations had introduced 200-mile zones of one kind or another.

83. Hardin, supra note 11.

84. Johnston, supra note 4 , at 14 .

85. Id.

86. Id.

87. Senate Hearing, supra note 9, at 30 (statement of Michael Tillman).

88. Convention on the Prohibition of Driftnet Fishing in the South Pacific, opened for signature Nov. 29, 1989, 29 I.L.M. 1449 (1990) [hereinafter "Wellington Convention']. 
driftnets larger than 2.5 kilometers within their EEZs, to prevent the landing or processing of driftnet catches, and to deny harbor access to driftnet vessels. ${ }^{89}$ Because a large expanse of the South Pacific is included in the EEZs of the signatory nations, and because the Wellington Convention prohibits driftnet vessels from crossing through those nations' EEZs, driftnetting is effectively illegal in much of the South Pacific. The United States, because of the presence of United States territories within the region, was eligible and did sign the Wellington Convention on November 14, 1990. Japan announced on August 15, 1990, that it had suspended driftnet fishing in the South Pacific, and Taiwan also agreed to suspend driftnetting by July $1,1991 .{ }^{90}$

\section{c. Other Regional Agreements}

Italy and France are discussing the creation of an international marine reserve in the occidental Mediterranean; the sanctuary will be created for cetaceans and other endangered species. The working group will be suggesting new restrictions on fishing concerning driftnets and additional monitoring of fishing by third countries. ${ }^{91}$

\section{U.N. Resolutions}

Initially, the United States and 17 other nations proposed a draft that recommended a "moratorium on all high-seas driftnet fishing by 30 June 1992 unless or until it is agreed that the unacceptable impact of such a practice can be prevented and that the conservation of the world's resources can be ensured." "92 "The effect of this draft would have been to terminate the use of driftnets on the high seas unless proponents of their use could carry the burden of securing agreement on means of preventing an 'unacceptable impact' and of ensuring conservation." 93 The Japanese countered with a resolution, ${ }^{94}$ noting that

89. Id.

90. Senate Hearing, supra note 9, at 30 (statement of Michael Tillman).

91. French Minister Announces Dolphin Sanctuary, Ban of Nets, INT'L ENv'T Daily (BNA), Oct. 26, 1992.

92. The draft was entitled "Large-scale Pelagic Driftnet Fishing and Its Impact on the Living Resources of the World's Oceans and Seas," UN Doc. A/C.2/44/L.30/ Rev.1, 15 November 1989. Other sponsors included Australia, Canada, Chile, Colombia, Fiji, Mauritania, Mexico, New Zealand, Papua New Guinea, Samoa, Solomon Islands, Sweden, Vanuatu, Zaire and Zambia.

93. William T. Burke, Driftnets and Nodules: Where Goes the United States?, 20 Ocean Dev. \& Int'l L. 237 (1990).

94. Draft G.A. Res. A/C.2/44/L.28 (Nov. 2, 1989). 
since some countries were concerned with the effects of driftnetting, regulation should be based on scientific data and analysis that would be regularly reviewed and a moratorium would be implemented if scientific data confirmed the need. ${ }^{95}$ The burden of proving detrimental effects was placed on nations opposing driftnetting. On December 22, 1989 , a compromise resolution ${ }^{96}$ was adopted unanimously, which called for a review of the "best available scientific data on the impact of large-scale pelagic driftnet fishing" by June 30, 1991, and "for the implementation of effective conservation and management measures which are based upon statistically sound analysis to be jointly made by concerned parties of the international community with an interest in the fishery resources of the region. . .,"97 The issue thus became how to gather scientific data on the impact of driftnet fishing on marine resources.

In the United States, concerns about the adverse effects of driftnetting were being heard from many constituencies. ${ }^{98}$ In response Congress passed and the President signed the Driftnet Impact Monitoring, Assessment, and Control Act of 1987..$^{99}$ This Act required the United States government to negotiate cooperative agreements with those countries that take United States marine resources in the North Pacific. ${ }^{100}$ Furthermore, the Act "called for negotiation of (1) adequate monitoring and assessment programs involving the deployment of scientific observers on driftnet vessels, and (2) adequate enforcement programs where significant U.S. marine resources, particularly salmon, may be taken." 101 To encourage the negotiation of these cooperative agreements, the Act also required the Secretary to certify, under the Pelly Amendment, ${ }^{102}$ any country that failed to enter such an agreement with the United States by June 29, 1989. If a country was certified, then the President has 60 days to report to the Congress on what, if any, imports

95. Davis, supra note 42 , at 1083.

96. G.A. Res. 44/225, supra note 65 .

97. Id., quoted in Burke, supra note 93, at 239.

98. Senale Hearing, supra note 9. See opening statements of Senators Adams, page 5; Burns, page 9; Gore, page 8; Gorton, page 6; Hollings, page 12; Kerry, page 1; Packwood, page 3; Stevens, page 10; and prepared statements of Senator Akaka, page 11 ; and Senator Inouye, page 74.

99. Driftnet Impact Monitoring, Assessment, and Control Act, 16 U.S.C. 1822 (1988) [hereinafter "'1987 Driftnet Act'].

100. Id. 4004 .

101. Senate Hearing, supra note 9, at 28 (statement of Michael Tillman).

102. 22 U.S.C.A. 1978 (West Supp. 1993). 
of fish and/or fishery products of the certified country would be embargoed under the Pelly Amendment. ${ }^{103}$

Under this threat of certification, Japan concluded such an agreement with Canada and the United States on June 23, 1989. Negotiations with Korea and Taiwan were concluded after the deadline and therefore, these countries were certified; however, no sanctions were imposed. The agreements were similar and provided that scientific observers tabulate catches on squid driftnet vessels, and that satellite transmitters on driftnetting vessels verify fishing locations. ${ }^{104}$ The results of data gathered by these scientific observation teams are summarized in the previous discussion dealing with the impacts of driftnet fishing. ${ }^{105}$

The U.N. again considered the use of large-scale driftnets on the high seas and adopted Resolution 46/215 without a vote on December $20,1991 .{ }^{106}$ The resolution called upon the international community to take three steps under section 3: (a) achieve a $50 \%$ reduction in the driftnet fishing effort by June 30,1992 by reducing the number of vessels involved, the length of the nets, and the area of operation; ${ }^{107}$ (b) continue to ensure that areas of operation of large-scale driftnet fishing are not expanded, but in fact are reduced in accordance with paragraph 3 (a); ${ }^{108}$ (c) and "ensure that a global moratorium on all large-scale pelagic driftnet fishing is fully implemented on the high seas" by December 31, 1992. ${ }^{109}$ The resolution further encourages members to "take measures individually and collectively, to prevent large-scale pelagic driftnet fishing operations on the high seas of the world's oceans." 110 The Secretary-General is to bring the resolution to the attention of both governmental, intergovernmental, and non-governmental organizations, as well as to scientific institutions with expertise in the field of living marine resources. ${ }^{111}$ U.N. members and the other organizations referred to in $\$ 5$, are to report to the SecretaryGeneral concerning activities or conduct inconsistent with this moratorium. ${ }^{112}$

103. Senate Hearing, supra note 9 , at 28 (statement of Michael Tillman).

104. Id. at 28, 29.

105. See supra Part IV.A. (reported driftnet catch data).

106. G.A. Res. 46/215, supra note 65 .

107. Res. $46 / 215$, I 3(a), supra note 67.

108. Res. 46/215, I3(b), supra note 67.

109. Res. 46/215, I 3(c), supra note 67 .

110. Res. 46/215, I 4, supra note 67.

111. Res. 46/215, I5, supra note 67 .

112. Res. 46/215, ๆ 6, supra note 67. 
The Preamble to Res. $46 / 215$ states a number of considerations which indicate the need for imposing this global moratorium. The most compelling consideration is that "members of the international community have reviewed the best available scientific data on the impact of large-scale pelagic driftnet fishing and have failed to conclude that this practice has no adverse impact which threatens the conservation and sustainable management of living marine resources," 113 and that the "grounds for concern expressed about the unacceptable impact of largescale pelagic driftnet fishing in resolutions $44 / 225^{114}$ and $45 / 197^{115}$ have been confirmed and evidence has not demonstrated that the impact can be fully prevented." 116 (emphasis added). Further considerations mentioned in the Preamble were that driftnetting was being expanded on the high seas to the Indian Ocean in contravention of the earlier resolutions, ${ }^{117}$. that several regional organizations had expressed their opposition to large-scale pelagic driftnet fishing, ${ }^{118}$ and that other members had decided to cease large-scale driftnet fishing on the high seas. ${ }^{19}$

\section{Role of Leverage Diplomacy and Environmental Activism}

Without the pressure created by nations opposed to the practice of large-scale driftnetting, this indiscriminate method of fishing the high seas would still be flourishing today. The actions of the United States in threatening sanctions under the Driftnet Monitoring and Assessment Act ${ }^{120}$ resulted in agreements that placed scientific observers on driftnetting vessels. The data collected by these observers allowed the international community to conclude that the concerns about the destructive effects on many species of marine life being voiced by the opponents of large-scale driftnetting were justified. No longer could driftnetting

113. Res. 46/215, supra note 67 (preamble).

114. Res. $44 / 225$, supra note 65 .

115. Res. 45/197, supra note 66 .

116. Res. 46/215, Preamble, supra note 67.

117. See, e.g., Senate Hearing, supra note 9, at 54 and 55 (statement of Nancy Daves, spokesperson for the Entanglement Network).

118. Wellington Convention, supra note 88. See also Castries Declaration, in which the Organization of Eastern Caribbean States resolved to establish a regional regime in the Lesser Antilles that would outlaw the use of driftnets, see $A / 46 / 344$, annex. of Res. 46/215, supra note 67.

119. South Korea Pressed to Ban Drift Nets; Japan's Decision to Quit Using Deadly Gear Puts the Focus on Seoul, Los Angeles Times, November 27, 1991, at A17.

120. 1987 Driftnet Act, supra note 99. 
nations argue that reliable scientific data was unavailable to assess the adverse impacts of the practice. The Wellington Convention closed much of the South Pacific to vessels that fished with large-scale driftnets. ${ }^{121}$ Nations, such as Japan, who wished access to the EEZs of this region, were forced to employ other, less destructive fishing techniques.

A number of environmental groups have expressed concern about the practice of large-scale driftnet fishing since it became widely practiced in the early 1980s. ${ }^{122}$ In 1983 and twice during 1990, Greenpeace launched expeditions in the Pacific to document driftnet fishing and its effects. ${ }^{123}$

During January 1990, . . G Greenpeace, using marine scientists, photographers, translators, scuba divers, and a skilled crew were able to obtain the first ever documentation of the impacts of this fishery. We observed over 16 species of fin fish, sharks and marine mammals dead and dying in the driftnets, including extremely rare species. ${ }^{124}$

In July, 1993, Greenpeace released video footage documenting the killing of whales by Italian fishing vessels using driftnets well in excess of the maximum 2.5 kilometre length sanctioned by the European Community. ${ }^{125}$ "Greenpeace has joined some 60 other non-governmental organisations in urging governments to commit themselves to 'fundamental, long-term and legally-binding reform to address the problems of declining fish stocks." 126 The public awareness created by the Greenpeace and Entanglement Network documentation of driftnetting in newspapers across North America and in Europe increased the call for action by governments. ${ }^{127}$

On November 3, 1992, President Bush signed a bill mandating trade sanctions against any country fishing with driftnets in the North Pacific in 1993 and extending the penalties to the North Atlantic in 1994. ${ }^{128}$ In the act, Congress finds that the U.N. specifically "encourages all members ... to take measures individually and collectively, to

121. Wellington Convention, supra note 88 .

122. Senate Hearing, supra note 9 , at 51.

123. Senate Hearing, supra note 9, at 41-48 (statement of Ben Deeble).

124. Id. at 45 .

125. Greenpeace Accuses EC Vessels of Flouting Driftnet Laws, Europe Information Service, July 20,1993 , at 414.

126. Id.

127. Groups Urge Signing of Drift-Net Bill, Seattle Times, Oct. 24, 1992, at A8.

128. High Seas Driftnet Fisheries Enforcement Act, supra note 62. 
prevent large-scale pelagic drift-net fishing operations on the high seas . . ."129 It is the stated policy of the United States to implement Res. $46 / 215$ and to secure a permanent ban on the use of destructive fishing practices, and in particular large-scale driftnets, by persons or vessels fishing beyond the Exclusive Economic Zone of any nation. ${ }^{130}$ The United States therefore will enforce sanctions against nations whose nationals or vessels are identified by the Secretary of Commerce as conducting such fishing. ${ }^{131}$ Sanctions include the denial of port privileges and prohibitions on imports of fish and fish products. If the prohibitions established under paragraph 3 are ineffective, additional sanctions on other imports such as televisions and cars are authorized. ${ }^{132}$ In March, 1993, the United States State Department announced that "if U.S. enforcement authorities have 'reasonable grounds' to believe any foreign flag vessel is conducting or has conducted large scale driftnet fishing, ... [and] [i]f the vessel is correctly registered, U.S. authorities will take appropriate 'law enforcement' action in accordance with agreements. ..."'133

Why is the United States taking this action to provide sanctions for driftnetting when the U.N. has passed Resolution 46/215 establishing a global moratorium on the practice, and the major driftnetting countries have announced that they will comply with the moratorium? Unfortunately, reports indicate that driftnetting is operating illegally. "Taiwanese officials have publicly stated that since 16 February 1990, it has been illegal for its driftnet vessels to operate in the Atlantic Ocean west of 20 degrees east longitude. However, as many as 160 Taiwanese boats are reported to be fishing ... around Tristan da Cunha, in the South Atlantic."'134 Often fishermen attempting to avoid their own government's scrutiny sail under a flag-of-convenience, a flag purchased from another, often poorer country. ${ }^{135}$ Environmental activist groups have been important in documenting the existence of this pirate industry. The Sea Shepherd Conservation Society, led by Paul Watson,

129. Res. $46 / 215$, supra note 67 .

130. 138 Cong. Rec. $\$ 11042(b)(3)(1992)$.

131. Title I, 101(3)(B)(b).

132. Bush Signs Drift-Net Bill, New York Times, Nov. 3, 1992, at D6, col. 6.

133. U.S. Says It Will Enforce Driftnet Fishing Moratorium, Reuter Asia-Pacific Business Report, March 8, 1993.

134. Senate Hearing, supra note 9 , at 55.

135. Driftnet Use Continues Despite Ban, The Gazetre (Montreal), July 19, 1993, at $\mathrm{B} 2$. 
"infiltrat[ed] heavily guarded docks in Kaosiung, Taiwan, [and] counted 40 new or refurbished boats, [and] another 27 being refitted for driftnetting. . . "136 "The National Marine Fisheries Service has documented millions of pounds of illegal salmon for sale on the world market, including at least 10 million pounds which was smuggled through the United States and sold in Japan."137 In May 1993, the United States Coast Guard sent two Chinese vessels believed to be violating the U.N. moratorium on driftnetting back to China. ${ }^{138}$

\section{Conclusion}

Without the existence of sanctions for countries that openly or illegally violate the U.N. moratorium, the difficulty of enforcement in the vast area of the world's oceans and the lure of quick profits provide a great temptation to continue driftnetting. Unilateral action to punish driftnetting nations with sanctions is one of the only enforcement tools that exist, given the lack of a U.N. environmental agency with regulatory power. Individual nations and regional organizations will need to use sanctions or denial of access to EEZs to pressure compliance with the U.N. moratorium on large-scale pelagic driftnetting until a binding multinational treaty exists which not only bans driftnetting but also has enforcement powers. In addition, environmental groups will play an important role by documenting illegal driftnetting in whatever dramatic ways they can and thereby continue to keep this issue before the world community.

"Driftnets are the scourge of our seas which indiscriminately destroy marine life and rapidly deplete our oceanic resources." ${ }^{139}$ Until the international law exists to adequately address the global environmental issues of today, the use of leverage diplomacy by individual nations and the activist confrontational techniques of groups such as Greenpeace and the Sea Shepherd Society will continue to play a critical role in addressing issues such as large-scale pelagic driftnetting.

Jane Kathryn Jenkins*

136. The Modern-Day Mariner Who Gives Piracy a Good Name, Indianapolis Star, Aug. 30, 1992, at F3.

137. Senate Hearing, supra note 9 at 51.

138. Coast Guard Sends Second Chinese Drifinetter Home, Reuters, LtD., May 20, 1993.

139. Senale Hearing, supra note 9, at 11 (statement of Senator Akaka).

- J.D. Candidate, 1994, Indiana University School of Law-Indianapolis. 